\title{
TSA Waste Stream and Final Waste Form Composition
}

\author{
J. D. Grandy \\ T. L. Eddy \\ G. L. Anderson
}

Published January 1993

Idaho National Engineering Laboratory

EG\&G Idaho, Inc.

Idaho Falls, Idaho 83415

Prepared for the

U.S. Department of Energy

Office of Environmental Restoration and Waste Management

Under DOE Idaho Field Office

Contract DE-AC07-76ID01570 


\begin{abstract}
A final vitrified waste form composition, based upon the chemical compositions of the input waste streams, is recommended for the transuranic-contaminated waste stored at the Transuranic Storage Area of the Radioactive Waste Management Complex at the Idaho National Engineering Laboratory. The quantities of waste are large with a considerable uncertainty in the distribution. of various waste materials. It is therefore impractical to mix the input waste streams into an "average" transuranic-contaminated waste. As a result, waste stream input to a melter could vary widely in composition, with the potential of affecting the composition and properties of the final waste form. This work examines the extent of the variation in the input waste streams, as well as the final waste form under conditions of adding different amounts of soil. Five prominent Rocky Flats Plant 740 waste streams are considered, as well as nonspecial metals and the "average" transuranic- contaminated waste streams. The metals waste stream is the most extreme variation and results indicate that if an average of approximately $60 \mathrm{wt} \%$ of the mixture is soil, the final waste form will be predominantly silica, alumina, alkaline earth oxides, and iron oxide. This composition will have consistent properties in the final waste form, including high leach resistance, irrespective of the variation in waste stream. For other waste streams, much less or no soil could be required to yield a leach resistant waste form but with varying properties.
\end{abstract}




\section{CONTENTS}

ABSTRACT $\ldots \ldots \ldots \ldots \ldots \ldots \ldots \ldots \ldots \ldots \ldots \ldots \ldots \ldots \ldots \ldots \ldots \ldots \ldots \ldots$

ACRONYMS $\ldots \ldots \ldots \ldots \ldots \ldots \ldots \ldots \ldots \ldots \ldots \ldots \ldots \ldots \ldots \ldots \ldots \ldots \ldots \ldots$

INTRODUCTION $\ldots \ldots \ldots \ldots \ldots \ldots \ldots \ldots \ldots \ldots \ldots \ldots \ldots \ldots \ldots \ldots \ldots$

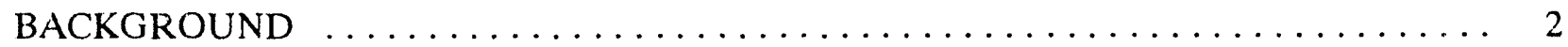

METHODOLOGY $\ldots \ldots \ldots \ldots \ldots \ldots \ldots \ldots \ldots \ldots \ldots \ldots \ldots \ldots$

WASTE FORM COMPOSITION $\ldots \ldots \ldots \ldots \ldots \ldots \ldots \ldots \ldots \ldots \ldots \ldots \ldots$

POTENTIAL PROBLEM AREAS IN FWF COMPOSITION $\ldots \ldots \ldots \ldots \ldots \ldots$

CONCLUSIONS AND RECOMMENDATIONS $\ldots \ldots \ldots \ldots \ldots \ldots \ldots \ldots \ldots \ldots \ldots$

REFERENCES ................................ 19

Appendix A-Final Slag Compositions $\ldots \ldots \ldots \ldots \ldots \ldots \ldots \ldots \ldots \ldots \ldots \ldots \ldots$

FIGURES

1. Plot of slag composition for the "Average" TRU-contaminated (A-Series)

waste as a function of mass of soil in the mixture $\ldots \ldots \ldots \ldots \ldots \ldots \ldots \ldots \ldots$

2. Pie charts of TRUW found in the TSA and SDA $\ldots \ldots \ldots \ldots \ldots \ldots \ldots \ldots \ldots$

3. Plot of slag composition for the RFP 741 hydrated metal oxide (H1-Series) waste as a function of mass of soil in the mixture $\ldots \ldots \ldots \ldots \ldots \ldots \ldots$

4. Plot of slag composition for the RFP 742 hydrated metal oxide (H2-Series) waste as a function of mass of soil in the mixture $\ldots \ldots \ldots \ldots \ldots \ldots$

5. Plot of slag composition for the RFP 743 calcium silicated (S-Series) waste

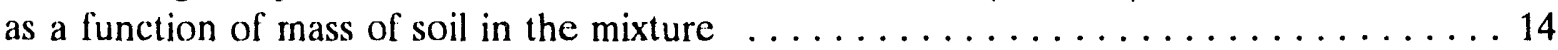

6. Plot of slag composition for the RFP 744 Portland cemented (P-Series) waste as a function of mass of soil in the mixture $\ldots \ldots \ldots \ldots \ldots \ldots \ldots \ldots \ldots$

7. Plot of slag composition for the RFP 745 alkali nitrate evaporator salt (N-Series) waste as a function of mass of soil in the mixture $\ldots \ldots \ldots \ldots \ldots \ldots$

8. Plot of slag composition for the nonspecial source metallic (M-Series) waste

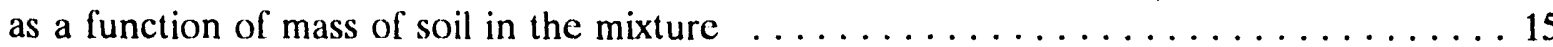




\section{TABLES}

1. Composition of "average" TRUW with various soil additions. A-40 is $40 \mathrm{wt} \%$ soil and $60 \mathrm{wt} \%$ average TRUW materials composition $\ldots \ldots \ldots \ldots \ldots \ldots$

2. Mass and volumes per category in selected areas of the RWMC $\ldots \ldots \ldots \ldots$

3. Waste material chemical compositions $\ldots \ldots \ldots \ldots \ldots \ldots \ldots \ldots \ldots \ldots$

4. Chemical compositions of common waste materials $\ldots \ldots \ldots \ldots \ldots \ldots \ldots \ldots \ldots$ 


\section{ACRONYMS}

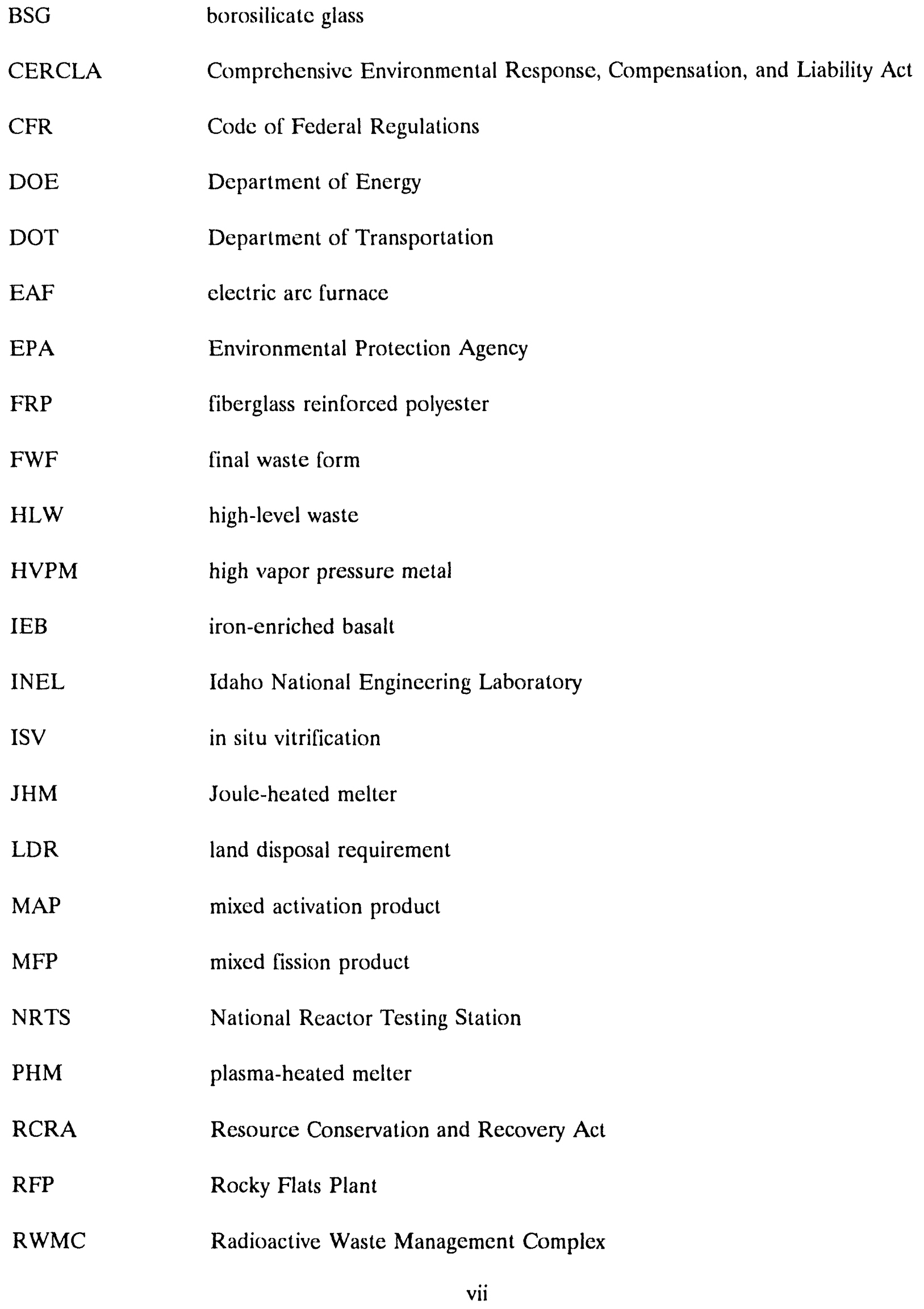




$\begin{array}{ll}\text { LL } & \text { low-level radionuclides } \\ \text { LLW } & \text { low-level waste } \\ \text { SDA } & \text { Subsurface Disposal Area } \\ \text { SDS } & \text { Preliminary System Design Study Report } \\ \text { TPT } & \text { Thermal Processing Technologies } \\ \text { TRA } & \text { Test Reactor Area } \\ \text { TRU } & \text { transuranic } \\ \text { TRUW } & \text { transuranic-contaminated waste } \\ \text { TSA } & \text { Transuranic Storage Area } \\ \text { USBM } & \text { U.S. Bureau of Mines } \\ \text { USGS } & \text { U.S. Geological Survey } \\ \text { WIPP } & \text { Waste Isolation Pilot Plant } \\ \text { WTD } & \text { Waste Technology Development }\end{array}$




\section{TSA Waste Stream and Final Waste Form Composition}

\section{INTRODUCTION}

This report examines the possibility that during waste processing, significant variations in the composition of a waste stream could produce an unsuitable final waste form (FWF). This possibility must be addressed, since there are various types of stored waste that differ enormously in composition. The average composition of transuranic-contaminated waste (TRUW) with $40 \mathrm{wt} \%$ soil has been shown to yield a high integrity FWF with excellent leach resistance and mechanical durability. Several waste types within the Transuranic Storage Area (TSA) will be analyzed to show that a usable FWF can be processed in spite of large variations in waste stream makeup. The waste types considered are representative of the limits in makeup of the waste, e.g., high alkaline or iron content. The elemental composition of the FWF is calculated by a simple proration of elements in the waste and soil additions minus any organic matter. Results for the TSA show that the addition of up to $60 \mathrm{wt} \%$ soil may be necessary to ensure an acceptable waste form, unless the input waste stream is presorted and mixed. 


\section{BACKGROUND}

Previous material studies and experiments directed toward development of a glass-ceramic FWF for treatment of wastes stored at the Radioactive Waste Management Complex (RWMC) have dealt with three separate waste compositions.' These were called the A-, B- and C-series slags and resulted respectively from the treatment of an "average" or nominal waste composition, first- and second-stage sludges from Rocky Flats in Colorado and combustible wastes. The average waste material composition, when mixed with various amounts of soil, would form an A-series slag with the compositions shown in Table 1. The values shown in the Table 1 were laken directly from an early (1981) informal report on IEB waste forms ${ }^{1}$. The A-series compositions are in the range of a ferro-alumino silicate, otherwise called an iron-enriched basalt (IEB), which has many desirable characteristics as a FWF. Figure 1 is a plot of the data in Table 1. The plot shows the makeup of the processed waste as a function of the wi\% soil that has been added. The change in any slag constituent can be easily followed as more soil is added to the melt. Soil is considered an easy way to increase the silica content of the slag, since there will be contaminated soil also needing processing.

The method for calculating the wt \% compositions is as follows. The A-series weight includes combustibles (organics, halides, sulfides, and other salts), unoxidized metals and noncombustibles (metal oxides). The soil is assumed to exclude moisture. Any moisture in the soil would have to be subtracted from the total soil weight. The preprocessed A-40 mixture is originally made of $60 \mathrm{wt} \%$ of "average" TRUW (combustible, noncombustible, and unoxidized metals) plus $40 \mathrm{wt} \%$ of dried soil. The molten slag, however, consists only of metal oxides. In the slag, the combustibles have been driven off, the unoxidized metals have been oxidized, and the noncombustibles (metal oxides) remain intact. The material mass fractions in the slag (wt\%) are therefore based only on the metals and metal oxides in the A-waste and soil. By letting the subscript i reler to a particular metal ( $\mathrm{Fc}, \mathrm{Al}, \mathrm{Mg}$, etc.), the mass fraction of metal oxide $\mathrm{MO}_{i}$ of metal $\mathrm{M}_{\mathrm{i}}$ in the slag can be determined from the following equation.

$$
\left(\mathrm{MO}_{\mathrm{i}}\right)_{a}=\frac{\left(\mathrm{MO}_{\mathrm{i}}\right)_{a}{ }^{*} \mathrm{~A}+\left(\mathrm{M}_{\mathrm{i}}\right)_{\mathrm{u}}{ }^{*} \mathrm{R}^{*} \mathrm{~A}+\left(\mathrm{MO}_{\mathrm{i}}\right)_{\mathrm{x}}{ }^{*} \mathrm{X}}{\Sigma_{\mathrm{i}}\left[\left(\mathrm{MO}_{\mathrm{i}}\right)^{*} \mathrm{~A}+\left(\mathrm{M}_{\mathrm{i}}\right)_{\mathrm{a}}{ }^{*} \mathrm{R}{ }^{*} \mathrm{~A}+\left(\mathrm{MO}_{\mathrm{i}}\right)_{\mathrm{x}}{ }^{*} \mathrm{X}\right]}
$$

where

subscript i refers an individual metal component

subscripts a, $x$ and $s$ refer to waste, soil and slag

$\left(\mathrm{MO}_{\mathrm{i}}\right)_{\mathrm{a}}$ is the wt\% of metal oxide, $\mathrm{MO}_{\mathrm{i}}$, in the waste

$\left(\mathrm{M}_{\mathrm{i}}\right)_{\mathrm{a}}$ is the wt\% of metal, $\mathrm{M}_{\mathrm{i}}$, in the waste

$\left(\mathrm{MO}_{\mathrm{i}}\right)_{\mathrm{x}}$ is the wt\% of metal oxide, $\mathrm{MO}_{i}$, in the soil 
Table 1. Composition of "average" TRUW with various soil additions. A-40 is $40 \mathrm{wt} \%$ soil and $60 \mathrm{wt} \%$ average TRUW materials composition.

\begin{tabular}{lccccccccc}
\hline & $\mathrm{SiO}_{2}$ & $\mathrm{Al}_{2} \mathrm{O}_{3}$ & $\begin{array}{c}\mathrm{FeO}+ \\
\mathrm{Fe}_{2} \mathrm{O}_{3}\end{array}$ & $\mathrm{CaO}$ & $\mathrm{MgO}$ & $\mathrm{Na}_{2} \mathrm{O}$ & $\mathrm{K}_{2} \mathrm{O}$ & $\mathrm{TiO}_{2}$ & $\mathrm{Misc}$. \\
\hline $\mathrm{A}-0$ & 38.0 & 7.4 & 34.5 & 8.3 & 4.6 & 4.8 & 2.4 & 0.1 & 0.0 \\
$\mathrm{~A}-20$ & 45.1 & 9.0 & 26.4 & 9.1 & 4.0 & 3.9 & 2.5 & 0.2 & 0.0 \\
$\mathrm{~A}-40$ & 51.0 & 10.3 & 19.6 & 9.7 & 3.5 & 3.2 & 2.6 & 0.3 & 0.0 \\
$\mathrm{~A}-60$ & 56.0 & 11.4 & 13.9 & 10.3 & 3.1 & 2.6 & 2.7 & 0.4 & 0.0 \\
$\mathrm{~A}-80$ & 60.6 & 12.1 & 9.5 & 10.0 & 2.8 & 2.2 & 2.8 & 0.5 & 0.0 \\
A-100 & 65.4 & 13.0 & 4.5 & 10.2 & 2.4 & 1.7 & 2.9 & 0.6 & 0.0 \\
\hline
\end{tabular}

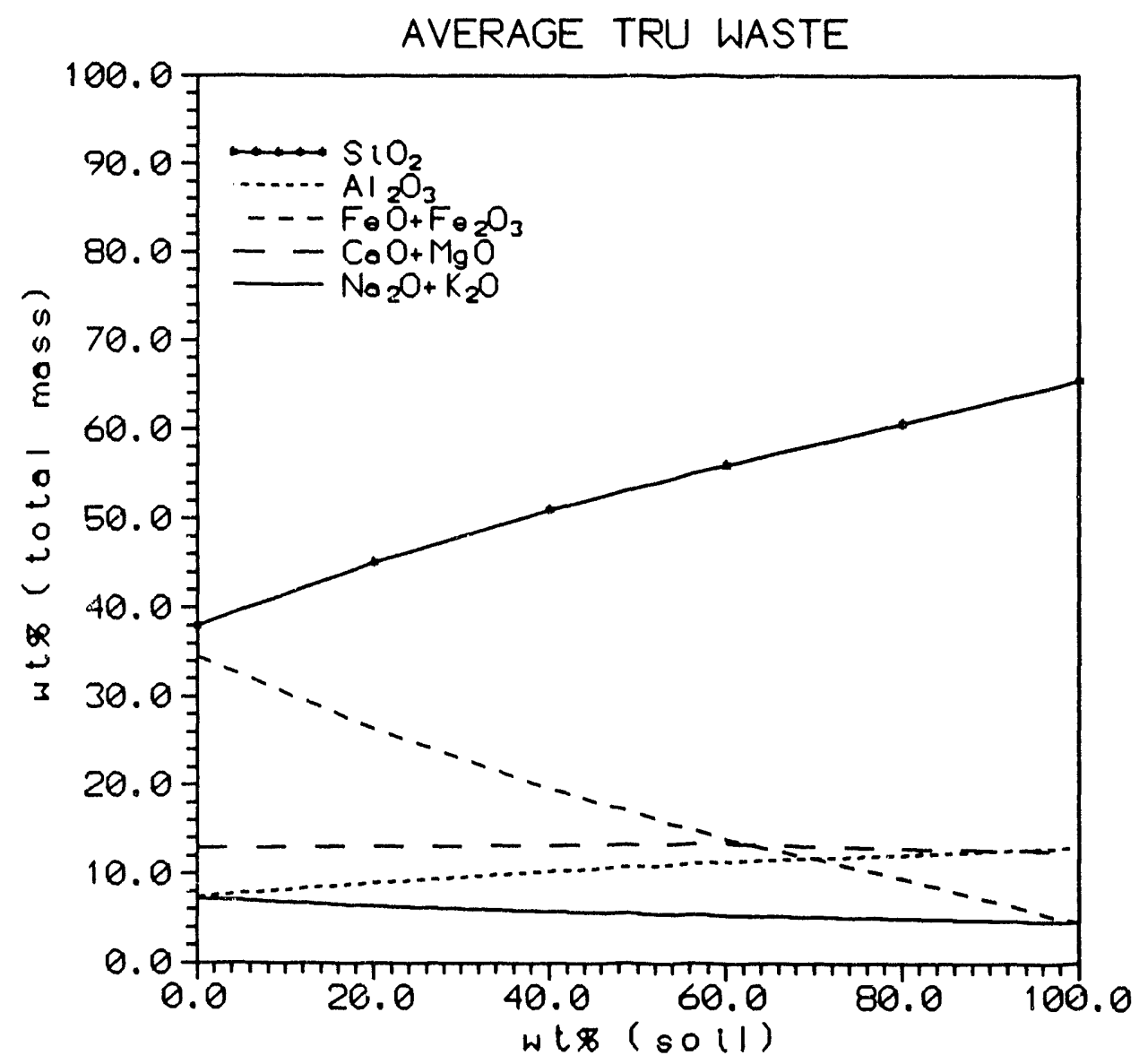

Figure 1. Plot of slag composition for the "Average" TRU-contaminated (A-Series) waste as a function of mass of soil in the mixture. 
A indicates the wt\% of waste $A$

$\mathrm{X}$ indicates the wt\% of soil

(and $\mathrm{A}+\mathrm{X}=100 \mathrm{wt} \%$ )

$\Sigma_{\mathrm{i}}$ is the sum over all metals and their oxides

$\mathrm{R}$ is the molecular-weight ratio of the oxide to the pure metal

Although using an average waste materials composition may be a good place to start an analysis toward a processing scheme, eventually, the realities of actually processing the waste will require a closer examination. Since the incoming waste stream will be comprised of many different materials contained in steel drums and boxes, an "average" waste composition does not physically exist unless all the materials can be mixed in a controlled fashion prior to processing. It is therefore important when establishing process limiting conditions to consider the waste stream as various materials being processed in turn.

The top pie chart in Figure 2 shows types of waste stored in the TSA. Although not exactly the same, they are similar in content of materials and mass fractions. The bottom pie chart shows types of waste stored in the Subsurface Disposal Area (SDA). Table 2 is a more detailed summation of the wastes. ${ }^{2,3}$ It also contains information on Pit 9, a specific area at the SDA.

The relation between input waste stream and slag waste form mass ratios can be determined as follows. Final slag composition is usually determined by prorating the slag contributors (metal oxides) in the input waste and the input soil according to the waste series compositional code, e.g., A-40. This proration method is valid for the input waste stream, the output offgas stream, and the output slag, because the sum of the offgas or slagging components in each of the actual input waste streams is a constant fraction of the total stream. This relationship does not include any oxygen required for combustion or metal oxidation. This relationship between volatilecombustible mass fractions and solid or slag components in the input waste stream can be put in an analytical form as shown below.

Consider an actual waste stream and soil mixture, Z-x, where the Z-series represents any of the wastes and $x$ represents the mass fraction of soil.

Then

$\mathrm{x}$

1-x $\quad=$ mass fraction of Z-series waste in mixture.

Let

$\mathrm{T} \quad=$ mass of total mixture 


\section{TSA Mass Fractions}

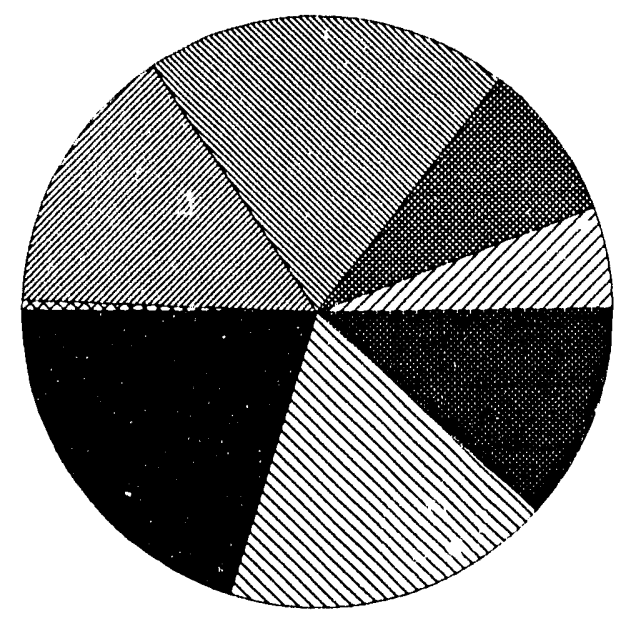

Legend

Organics/Ca Silicate

Cemented Organics

$\mathrm{Na/K}$ Nitrates

Hydrated Oxides

Acids \& Bases

Bricks,Concrete etc

HVPM/Reactive Metals

other Metals

misc. Combustible

Unclassified

\section{SDA Mass Fractions}

\section{i}

Legend

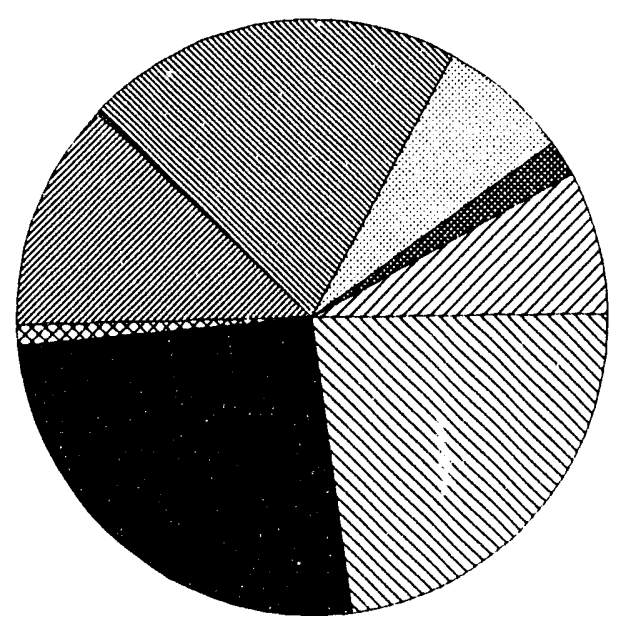

Organics/Ca Silicate

Cemented Organics

Na/K Nitrates

Hydrated Oxides

Acids \& Bases

Bricks,Concrete,etc

HPVM/Reactive Metals

other Metals

misc. combustible

Unclassified

Figure 2. Pie charts of TRUW found in the TSA and SDA. 


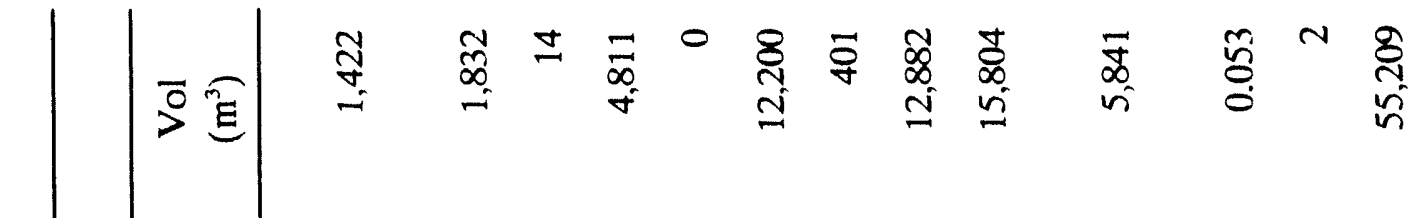

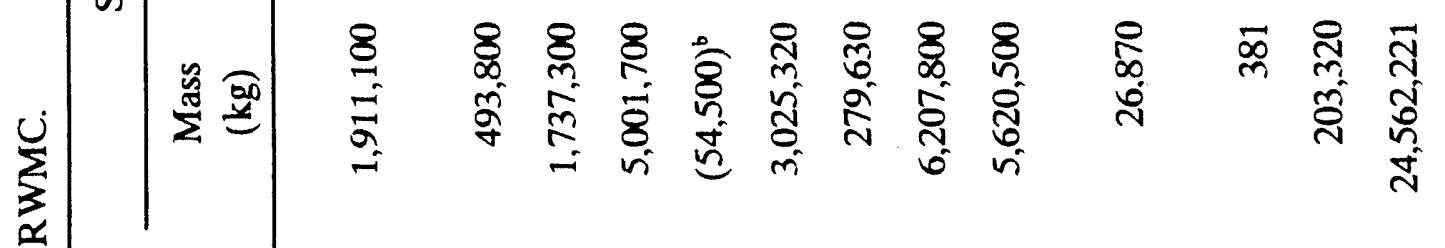

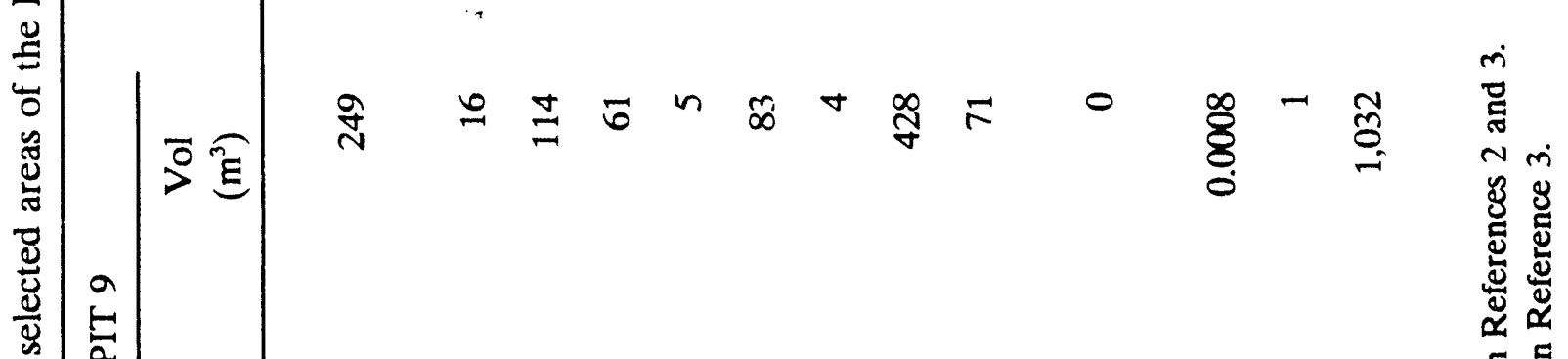

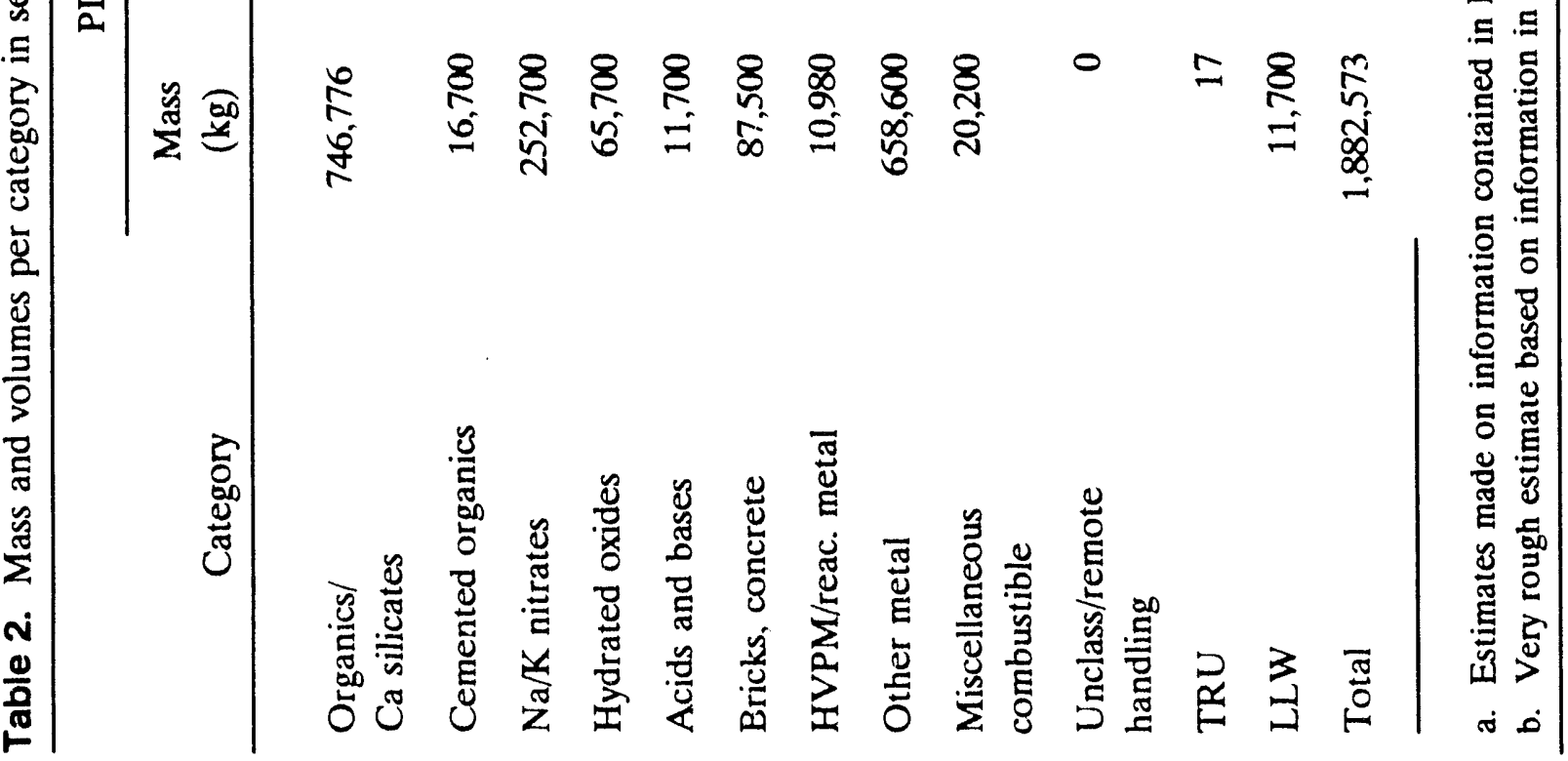




$$
\begin{array}{ll}
\mathrm{T}_{z}=(1-\mathrm{x}) \mathrm{T} & =\text { mass of } \mathrm{Z} \text {-series waste in total mixture } \\
\mathrm{T}_{\mathrm{x}}=\mathrm{xT} & =\text { mass of soil in total mixture } \\
\mathrm{V}_{\mathrm{z}} & =\text { volatile-combustibie masses in the Z-waste } \\
\mathrm{V}_{\mathrm{x}} & =\text { volatile-combustible masses in the soil } \\
\mathrm{S}_{z} & =\text { slag (metal oxide) masses in the Z-waste } \\
\mathrm{S}_{\mathrm{x}} & =\text { volatile-combustible mass fraction in the Z-waste } \\
\mathrm{v}_{\mathrm{z}} & =\text { volatile-combustible mass fraction in the soil } \\
\mathrm{v}_{\mathrm{x}} & =\text { slag (metal oxide) mass fraction in the waste } \\
\mathrm{s}_{\mathrm{z}} & =\text { slag (metal oxide) mass fraction in the soil. } \\
\mathrm{s}_{\mathrm{x}} &
\end{array}
$$

Then

$$
\begin{aligned}
& \mathrm{T}_{\mathrm{z}}=\mathrm{V}_{\mathrm{z}}+\mathrm{S}_{\mathrm{z}}, \mathrm{T}_{\mathrm{x}}=\mathrm{V}_{\mathrm{x}}+\mathrm{S}_{\mathrm{x}} \\
& \mathrm{v}_{\mathrm{z}}=\mathrm{V}_{\mathrm{z}} / \mathrm{T}_{\mathrm{z}}, \mathrm{v}_{\mathrm{x}}=\mathrm{V}_{\mathrm{x}} / \mathrm{T}_{\mathrm{x}} \\
& \mathrm{s}_{\mathrm{z}}=\mathrm{S}_{\mathrm{z}} / \mathrm{T}_{\mathrm{z}}, \mathrm{s}_{\mathrm{x}}=\mathrm{S}_{\mathrm{x}} / \mathrm{T}_{\mathrm{x}}
\end{aligned}
$$

And

$$
\begin{aligned}
& T=T_{z}+T_{x}=V_{z}+S_{z}+V_{x}+S_{x} \\
& T=T_{z}\left(v_{z}+s_{z}\right)+T_{x}\left(v_{x}+s_{x}\right) .
\end{aligned}
$$

Dividing by $\Upsilon$ and rearranging

$$
\left.\left.1=\left[(1-x) v_{z}+(x) v_{x}\right)\right]+\left[(1-x) s_{z}+(x) s_{x}\right)\right]
$$

In this equation, the mass fraction of volatile-combustible material is the first bracket, and the second bracket contsitutes the slag mass fraction. Each waste steam (identified by content code) can be characterized by the amounts contained in each bracket.

This equation could casily be used to prorate individual waste streams (e.g., Z-x) in a mixed waste stream input into slag residues, and volatile-combustible offgas streams according to $x$ and 1 -x proportions. However, any oxygen added to combust organics or oxidize metals must be added to the respective stream. 


\section{METHODOLOGY}

If the waste stream consists of a succession of different waste types, (combustibles, metals, glass, etc.) each type could be analyzed to optimize the processing. However, there are more than 100 different content codes ${ }^{4}$ for waste in the TSA; and although many codes are similar in the waste materials they contain, customizing the processing for individual materials or mixtures would be a complex task that may be unnecessary. An alternate approach is to pick several waste materials that will represent the composition limits for important slag constituents. Content Codes 1-5, plus Content Code 480, fulfill this requirement. The rest of the waste falls within the composition limits of these six waste types, which are identified in Table 3 and discussed below.

Content Codes 1 and 2 are hydrated metal oxide sludges. Besides heavy metals, Content Code 1 (first stage sludge) contains a significant percentage of alkalines, and Code 2 (second stage sludge) contains a high percentage of earth alkalines. Content Code 3 is composed of oils and cleaning agents. These organic liquids are mixed with large amounts of calcium silicate (Microcel E) as part of the packaging process. Code 4 contains even higher amounts of earth alkalines than Code 2 but contains different amounts of silica and iron oxides. Code 5 (evaporator salts) is mostly sodium and potassium nitrates. Code 480 is predominately metal, steel, and iron, with some copper and aluminum. Other waste streams have a high percentage of silica, Code 440 (glass) for example; but a high silica content should not present a problem in slag formation, especially since the steel drum containers will provide the iron content to form an IEB.

Table 3 contains an overview of each of the waste categories. In this table, the entries are for the original waste as generated by Rocky Flats. The chemical compositions, listed under the heading "Original waste chemical composition," do not include any additions made in the interest of packaging or solidifying. The next column lists the main additives that were combined with the waste material during packaging. Chemical compositions of the various waste materials is also available in previously published reports. ${ }^{4,5}$

The last column in Table 3 lists proposed designators for the various types of slags resulting from processing the particular waste category. The designators $(\mathrm{H} 1, \mathrm{H} 2, \mathrm{M}, \mathrm{N}, \mathrm{P}, \mathrm{S})$ are similar to the A designation for the slag resulting from processing an "average" TRUW. H1 and H2 designate hydrated metal oxides. $\mathrm{M}$ and $\mathrm{N}$ designate metals and nitrates respectively. Portland cemented organics or special setups are designated by $\mathrm{P}$, and organic setups made with calcium silicate to solidify them are designated with an S. These designators will be used in remaining tables and figures to indicate the type of waste slag.

It is assumed that the waste packaging material will be processed along with original waste and must therefore be included as part of the waste stream. Waste packaging and handling sometimes included mixing extra materials with the waste to produce something caser to handle like the sludge produced by adding calcium silicates to liquid organics (Code 3). Additional materials such as vermiculite, "oil dry," or Portland cement were usually added to soak up any stray liquids that might accumulate in the container. Details of the packaging process and additions made during the processing for all content codes can be found in an internal technical report by Clements. ${ }^{4}$ Table 4 shows the chemical compositions ${ }^{4,6}$ for many of the waste stream substances, including the packaging materials mentioned. The waste is stored in either 55-gal steel drums, steel bins or wooden boxes. The boxes are usually made of plywood and coated with 
Table 3. Waste material chemical compositions.

\begin{tabular}{|c|c|c|c|c|}
\hline $\begin{array}{l}\text { Content code/ } \\
\text { name }\end{array}$ & RFP & $\begin{array}{c}\text { Original waste } \\
\text { chemical composition } \\
(\mathrm{wt} \%)\end{array}$ & $\begin{array}{c}\text { Primary packaging } \\
\text { additions }\end{array}$ & Designator \\
\hline $\begin{array}{l}\text { 1/first stage } \\
\text { sludge }\end{array}$ & 741 & $\begin{array}{l}\mathrm{H}_{2} \mathrm{O}(60 \%), \mathrm{SiO}_{2}(14 \%), \\
\mathrm{Al}_{2} \mathrm{O}_{3}(3 \%), \\
\mathrm{FeO}(0 \%), \mathrm{Fe}_{2} \mathrm{O}_{3}(3 \%), \\
\mathrm{MgO}(2 \%), \\
\mathrm{CaO}(2 \%), \mathrm{Na}_{2} \mathrm{O}(11 \%), \\
\mathrm{K}_{2} \mathrm{O}(2 \%) \text {, other }(3 \%)\end{array}$ & Portland cement & (H1) \\
\hline $\begin{array}{l}2 / \text { second stage } \\
\text { sludge }\end{array}$ & 742 & $\begin{array}{l}\mathrm{H}_{2} \mathrm{O}(60 \%), \mathrm{SiO}_{2}(19 \%), \\
\mathrm{Al}_{2} \mathrm{O}_{3}(2 \%), \\
\mathrm{FeO}(0 \%), \mathrm{Fe}_{2} \mathrm{O}_{3}(2 \%), \\
\mathrm{MgO}(4 \%), \\
\mathrm{CaO}(10 \%), \mathrm{Na}_{2} \mathrm{O}(2 \%) \\
\mathrm{K}_{2} \mathrm{O}(1 \%), \text { other }(0 \%)\end{array}$ & Portland cement & $(\mathrm{H} 2)$ \\
\hline 3/organic setups & 743 & $\begin{array}{l}\text { Texaco regal oil }(28 \%) \text {, } \\
\mathrm{CCl}_{4}(19 \%), \\
\mathrm{Cl}_{2} \mathrm{CHCH} \mathrm{Cl}_{2}(10 \%), \\
\text { misc. oils (hydraulic, } \\
\text { gearbox, freon, etc.) } \\
(43 \%)\end{array}$ & Calcium silicates & (S) \\
\hline 4/special setups & 744 & $\begin{array}{l}\text { Alcohols, organic acids } \\
\text { and } \\
\text { chelating agents }(100 \%) \\
\text { (specific makeup } \\
\text { unknown) }\end{array}$ & $\begin{array}{l}\text { Portland cement, } \\
\text { magnesia cement }\end{array}$ & (P) \\
\hline 5/evaporator salts & 745 & $\begin{array}{l}\mathrm{NaNO}_{3}(60 \%) \\
\mathrm{KNO}_{3}(30 \%) \\
\text { misc. }(10 \%)\end{array}$ & None & $(\mathrm{N})$ \\
\hline $\begin{array}{l}\text { 480/unleached } \\
\text { light non-SS } \\
\text { source metal }\end{array}$ & UNK & $\begin{array}{l}\mathrm{Fe}(62 \%), \\
\text { other(Cu,Al,Cr,etc. }) \\
(26 \%) \\
\mathrm{SiO}_{2}(3 \%), \mathrm{Al}_{2} \mathrm{O}_{3}(2 \%) \\
\mathrm{CaO}(2 \%) \\
\text { other(combustible })(5 \%)\end{array}$ & None & $(\mathrm{M})$ \\
\hline
\end{tabular}


Table 4. Chemical compositions of common waste materials.

Waste material

Glass (amorphus silica)

$\mathrm{SiO}_{2}(100 \%)$

Tantalum

$\mathrm{Ta}(100 \%)$

Steel

$\mathrm{Fe}(99 \%), \mathrm{C}(1 \%)$

Stainless steel

$\mathrm{Fe}(74 \%), \mathrm{Cr}(18 \%), \mathrm{Ni}(8 \%)$

Lead

$\mathrm{Pb}(100 \%)$

Other metals

$\mid \mathrm{Al}, \mathrm{Cu}, \mathrm{Zn}, \mathrm{Ni}, \mathrm{Hg}, . .$.

Surgeon's glove (rubber)

$\left(\mathrm{C}_{2}, \mathrm{H}_{4}\right)_{\mathbf{x}}(100 \%)$

Combustible (wood,

cardboard, paper, cloth)

$\mathrm{C}_{6} \mathrm{H}_{10} \mathrm{O}_{5}(100 \%)$

Plastic (polyvinyls)

$\left(\mathrm{C}_{2} \mathrm{H}_{4}\right)_{\mathbf{x}}(100 \%)$

Rubber

$\left(\mathrm{C}_{2} \mathrm{H}_{4}\right)_{x}(100 \%)$

Leaded rubber

$\left(\mathrm{C}_{2} \mathrm{H}_{4}\right)_{\mathbf{x}}(?) \mathrm{Pb}(?)$

Resins

$\mathrm{C}_{44} \mathrm{H}_{62} \mathrm{O}_{4}(100 \%)$

Firebrick (Plicast 40)

$\mathrm{Al}_{2} \mathrm{O}_{3}(96 \%), \mathrm{CaO}(4 \%)$

Salts

Evaporator salts

Pyrochemical salt waste

Molten salts

Electrorefining salt

Gibson salts

$\mathrm{NaNO}_{3}(60 \%), \mathrm{KNO}_{3}(30 \%), \operatorname{misc}(10 \%)$

[?]

$\mathrm{NaCl}(?), \mathrm{KCl}(?), \mathrm{MgCl}_{2}(?)$

[?]

$\mathrm{CaCl}_{2}(?), \mathrm{KCl}(?)$

Concrete (cement + rocks?)

$\mathrm{CaO} \& \mathrm{Al}_{2} \mathrm{O}_{3} \cdot 2 \mathrm{SiO}_{2} \cdot 2 \mathrm{H}_{2} \mathrm{O}$

Vermiculite

$\mathrm{SiO}_{2}(42 \%), \mathrm{Al}_{2} \mathrm{O}_{3}(12 \%), \mathrm{Fe}_{2} \mathrm{O}_{3}(19 \%)$,

$\mathrm{MgO}(27 \%)$

Portland cement

$\mathrm{SiO}_{2}(25 \%), \mathrm{Al}_{2} \mathrm{O}_{3}(12 \%), \mathrm{Fe}_{2} \mathrm{O}_{3}(1 \%), \mathrm{CaO}(60 \%)$, misc. $(2 \%)$

Magnesia cement

$\mathrm{MgCl}_{2}(20 \%), \mathrm{MgCO}_{3}(80 \%)$

Microcel E

$\mathrm{SiO}_{2}(63 \%), \mathrm{Al}_{2} \mathrm{O}_{3}(4 \%), \mathrm{Fe}_{2} \mathrm{O}_{3}(1), \mathrm{CaO}(29 \%)$,

$\mathrm{MgO}(1 \%), \mathrm{Na}_{2} \mathrm{O}(1 \%), \mathrm{K}_{2} \mathrm{O}(1 \%)$

Oil-Dri (montmorillonitc)

$\mathrm{SiO}_{2}(61 \%), \mathrm{Al}_{2} \mathrm{O}_{3}(27 \%), \mathrm{Fe}_{2} \mathrm{O}_{3}(3 \%), \mathrm{FcO}(1 \%)$,

$\mathrm{MgO}(5 \%), \mathrm{CaO}(2 \%), \mathrm{K}_{2} \mathrm{O}(1 \%)$

Asbestos (chrysotile)

$\mathrm{SiO}_{2}(41 \%), \mathrm{MgO}(41 \%), \mathrm{H}_{2} \mathrm{O}(14 \%), \mathrm{FcO}$,

$\mathrm{Fe}_{2} \mathrm{O}_{3}(3 \%), \mathrm{AlO}_{3}(1 \%)$ 
fiberglass reinfored polyester (FRP). Since they are organic, the boxes do not affect the slag composition. The steel drums will make a significant contribution to the iron oxide content of the slag. A typical drum of the type used to store waste has a mass of approximately $23.6 \mathrm{~kg}$.

To determine the final waste material composition after undergoing processing in a melter, some chemical reaction assumptions must be made. A general assumption is that all organics will undergo decomposition and eventual oxidation to produce $\mathrm{H}_{2} \mathrm{O}, \mathrm{CO}_{2}, \mathrm{~N}_{2}$, etc. In addition, most free metals will oxidize and become part of the slag. The ultimate fate of volatile metals like $\mathrm{Hg}$, $\mathrm{Pb}$, etc., of offgases like $\mathrm{CO}, \mathrm{SO}_{2}, \mathrm{NO}_{\mathrm{x}}$, etc., and of halogens like $\mathrm{Cl}, \mathrm{Fl}$, etc., has not been considered since it is beyond the scope of this work.

In summary, the final slag composition is calculated by assuming that the organics will be burned off, and the mass is adjusted. Any free metals are assumed to be oxidized, and the metal (oxide) mass is increased accordingly. This is done for all waste stream components: waste, packaging materials, and container. The primary components for the slag are added up and the weight percents calculated. 


\section{WASTE FORM COMPOSITION}

Figures 3-8 and the six tables in Appendix A show final slag compositions. In the same manner as the A-scries slags, H1-0, M-0, etc. represent slag compositions with no soil added. These values are represented on the left ordinate of the plots. The results of suceessive soil additions to the waste stream are plotted on the $\mathrm{X}$-axis. The range goes from $0 \mathrm{wt} \%$ soil added to $100 \mathrm{wt} \%$. These results can be compared to Figure 1 and Table 1, which show the A-scries slags for an "average" waste composition.

Figure 3, Figure 4, and the first two tables in Appendix A for hydrated metal sludges are representative of first- and second-stage sludges processed at Rocky Flats. Together, these two categories make up approximately 13 pereent of the total mass in the TSA. Sludge samples from each process were taken and analyzed in 1981.5 The H-() composition in the tables and graphs are the average of the resulting data and therefore do not represent the most extreme cases possible, as far as $\mathrm{Na}$ and $\mathrm{K}$ concentrations in the case of the first-stage sludge and $\mathrm{Mg}$ and $\mathrm{Ca}$ concentrations in the case of the second-stage sludge. In the extreme case, based on a single sample, the concentrations could be 10 percent higher in each case above the average value shown.

Figure 5 shows the data for "organic setups," which make up $5 \frac{1}{2}$ percent of the total TSA waste. The high calcium oxide content is the result of mixing the liquid organic waste with large amounts of calcium silicates. The iron content is due almost entirely to the steel drum container.

The organic sludge in Figure 6 is similar, except that Portland eement and pipe cement are the main packaging additives. This results in the high concentration $(50 \%)$ of earth alkalines, $\mathrm{MgO}$ and $\mathrm{CaO}$, in the final slag composition. This waste amounts to only $1 \frac{1}{2}$ percent of the TSA total.

An extreme compositional excursion is shown in Figure 7 for evaporator salts. The nitrate salts oxidize to form earth alkalines composing $74 \%$ of the slag, with the steel drum making up the rest. However, the percentage of the TSA waste making up this category is much less than 1 percent.

Another extreme is shown in Figure 8 for "unleached metals." Naturally, the resulting slag makcup is nearly all metallic oxides. The waste makeup for this category was taken from a recent waste steam inventory report." This particular category (Code 480) makes up a substantial part $(17.3 \%)$ of TSA waste, the majority of which is stored in boxes. The boxes would be combusted and not end up in the slag; therefore, Figure 8 is based on steel drum packaging.

a. J. D. Mousscau, Private Sector Participation Initiative - Transuranic and Reclassified Transuranic Waste veream Draft Report - JDM-31-91, EG\&G Idaho, Inc., Interoffice Correspondence, Dec. 20, 1991. 


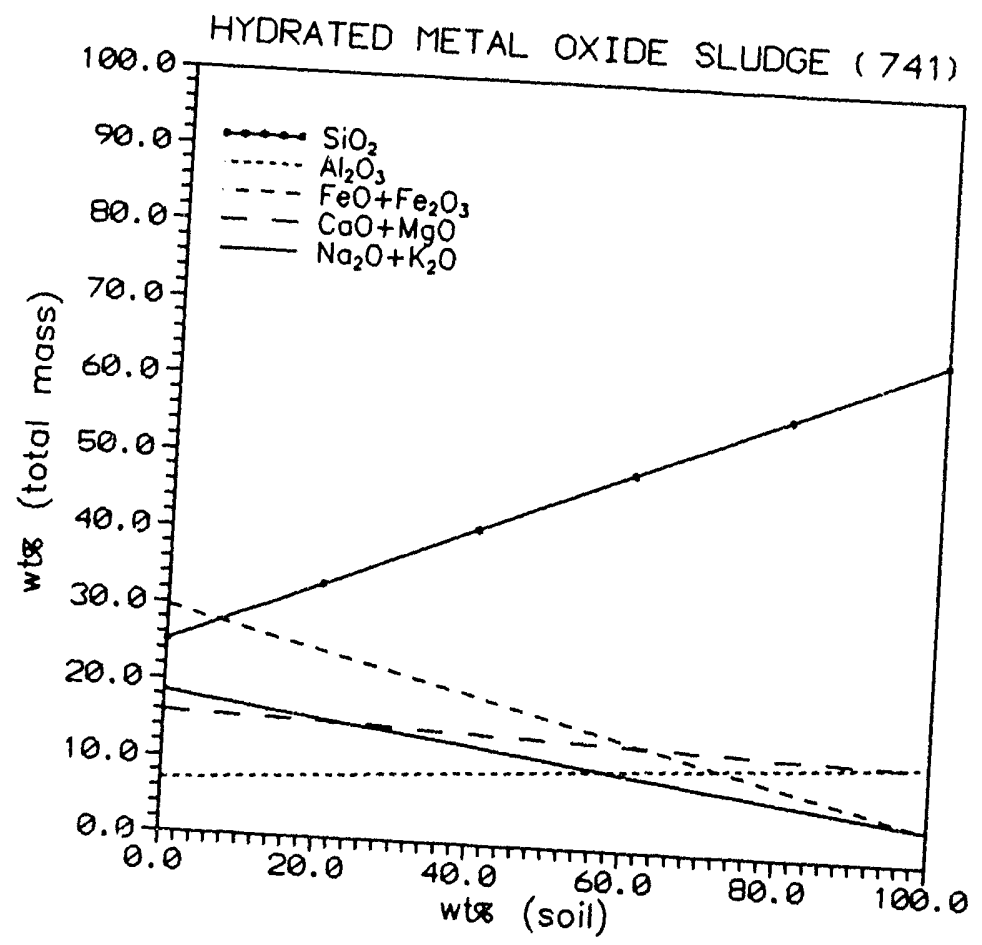
Figure 3. Plot of slag composition for the RFP 741 hydrated metal oxide (H1-Series) waste as a
function of mass of soil in the mixture.

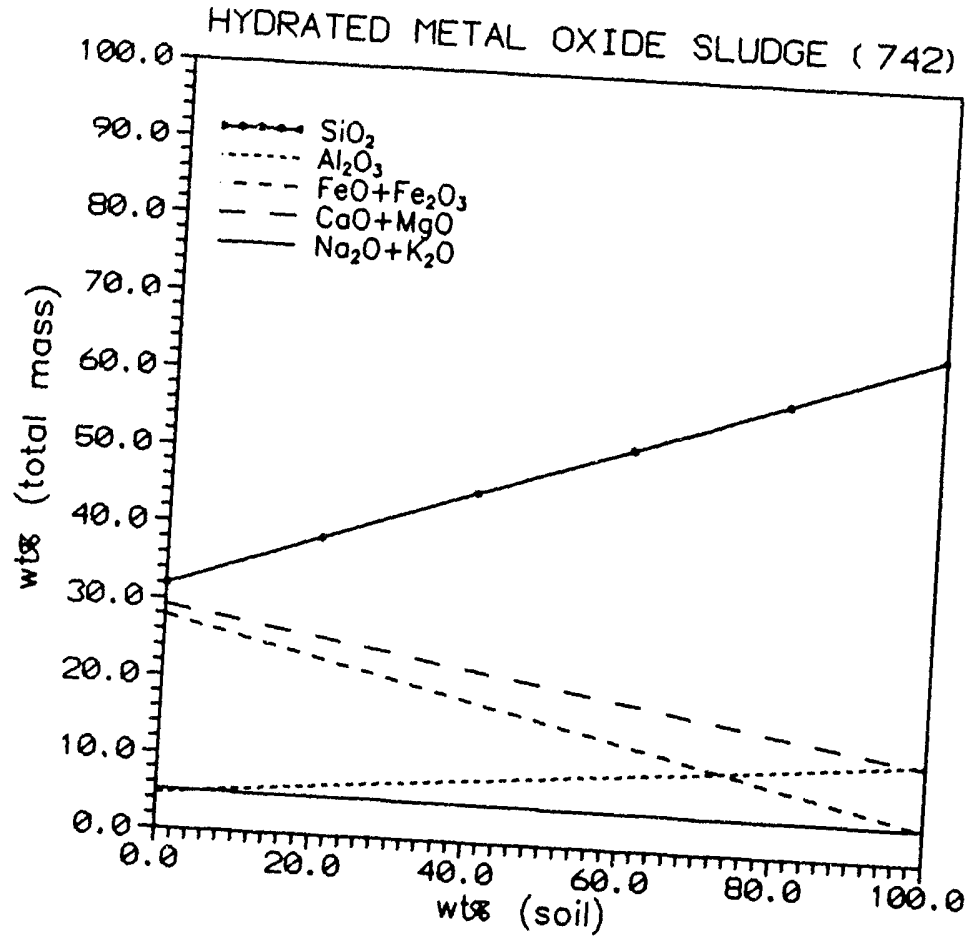

Figure 4. Plot of slag composition for the RFP 742 hydrated metal oxide (H2-Series) waste as a
function of mass of soil in the mixture 


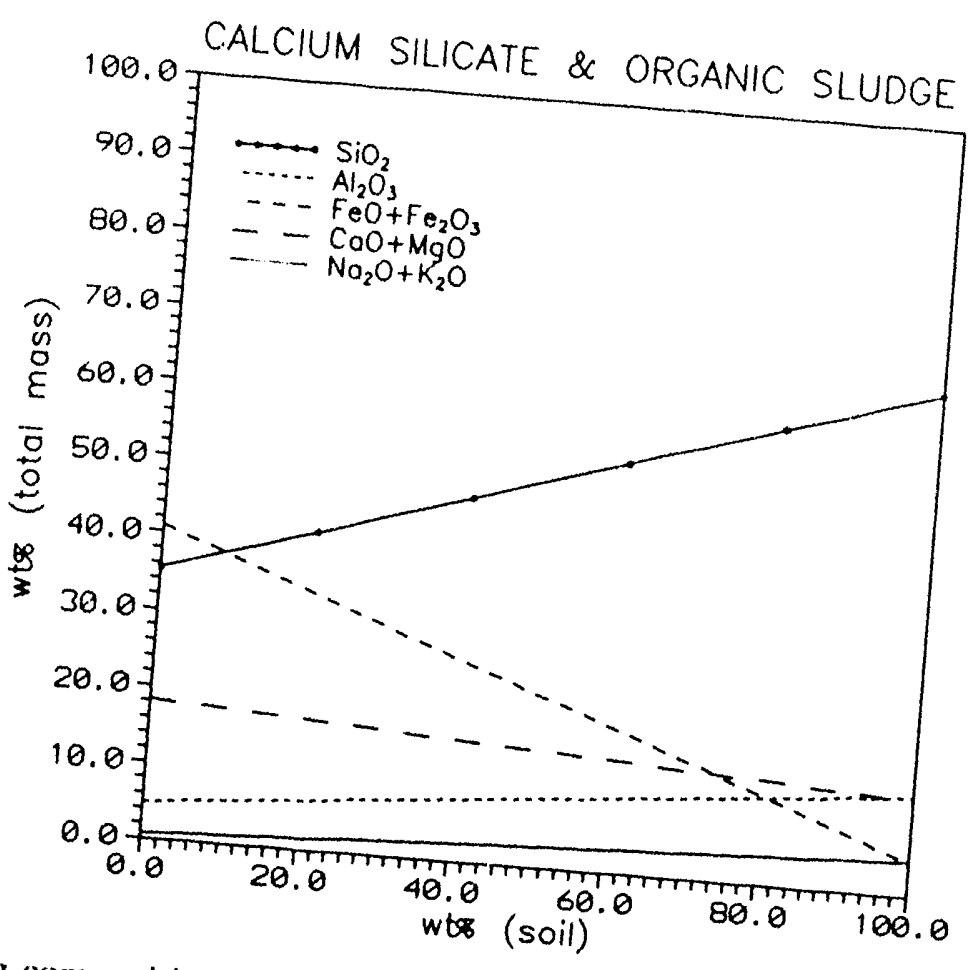

Figure 5. Plot of

function of mass of soil in the mixture.

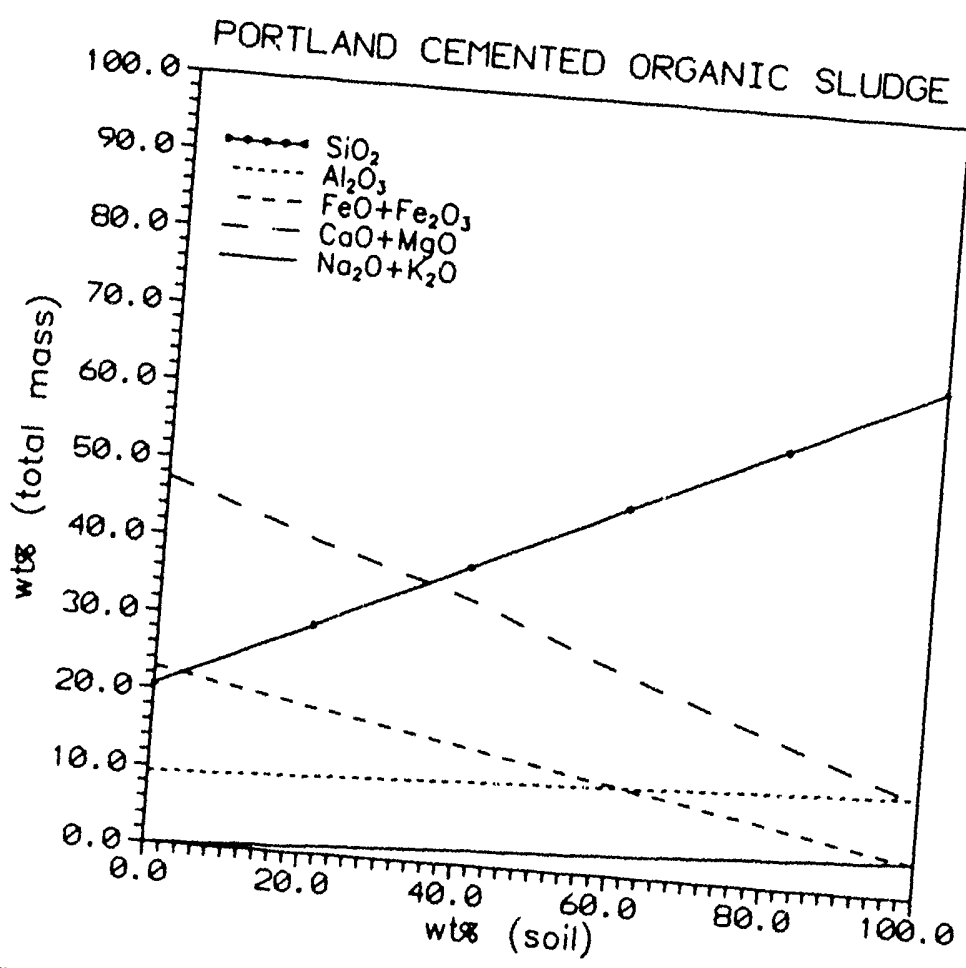

Figure 6. Plot of slag composition for the RFP 744 Portland cemented (P-Scries) waste as a
function of mass of soil in the mixture. 


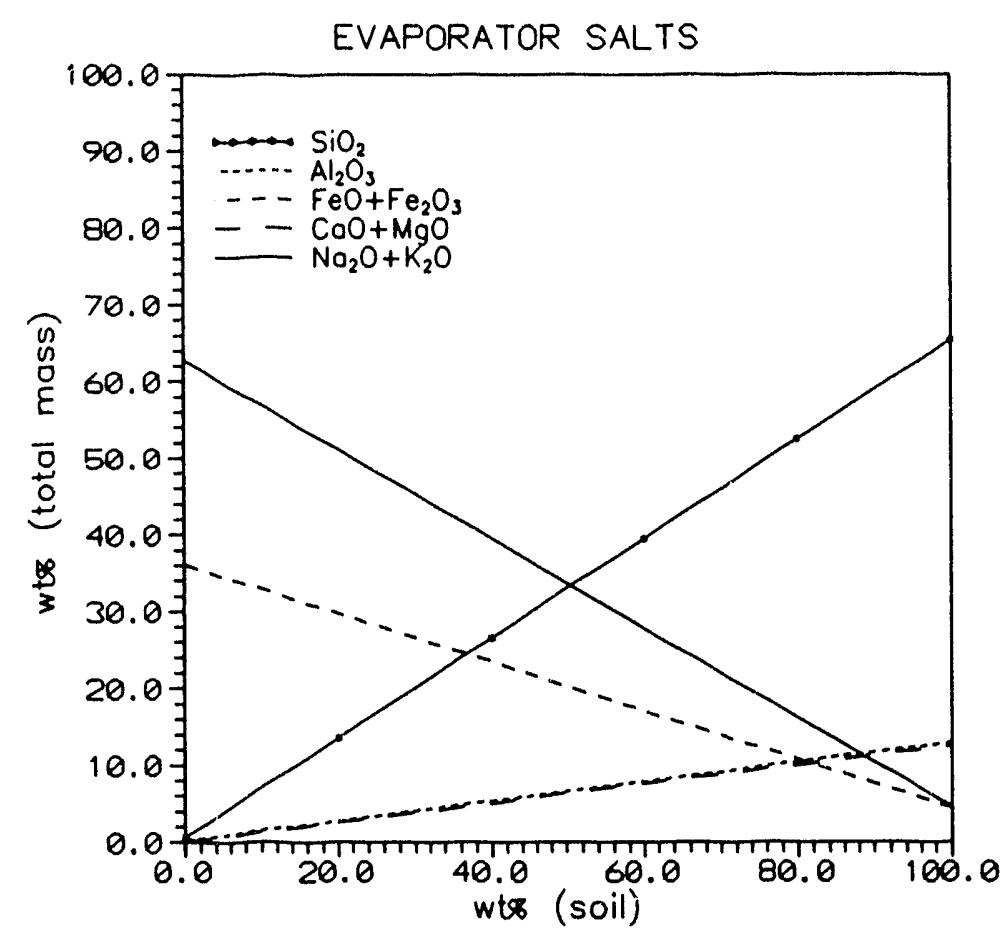

Figure 7. Plot of slag composition for the RFP 745 alkali nitrate evaporator salt (N-Series) waste as a function of mass of soil in the mixture.

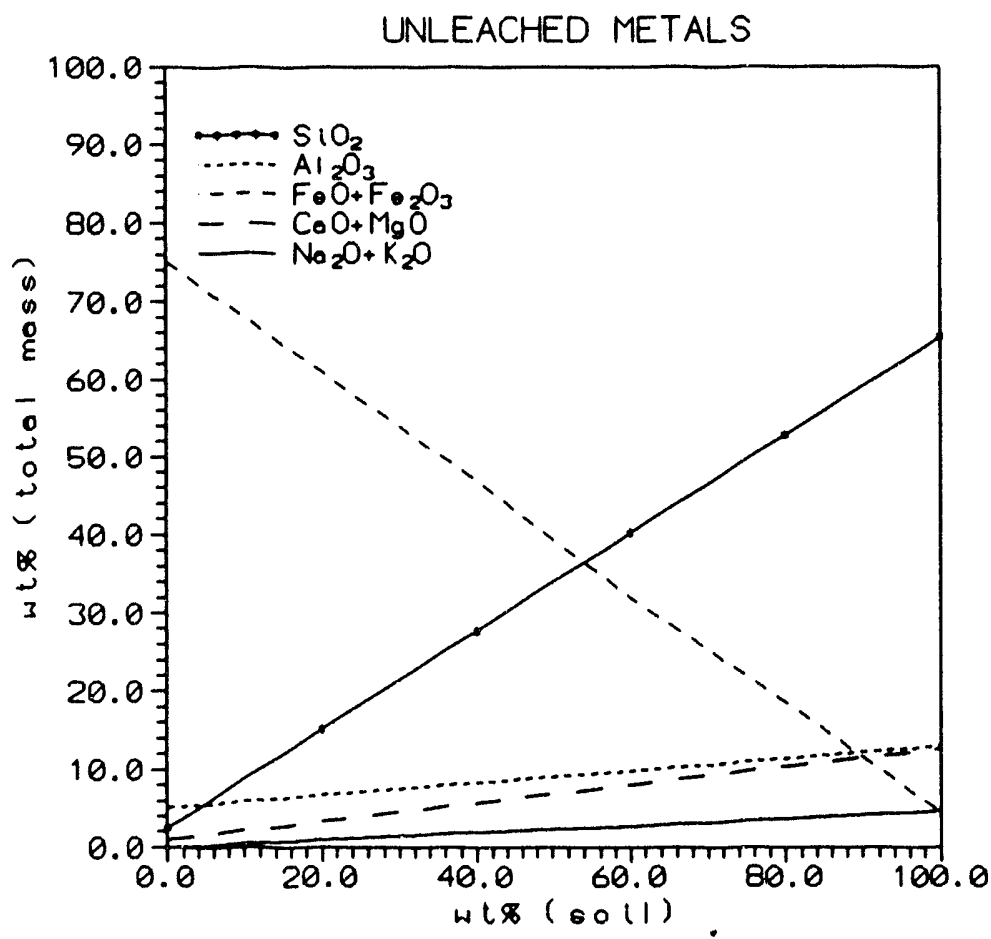

Figure 8. Plot of slag composition for the nonspecial source metallic (M-Series) waste as a function of mass of soil in the mixture. 


\section{POTENTIAL PROBLEM AREAS IN FWF COMPOSITION}

In discussing the material composition limits for each of the waste streams described above, some type of eritera or standard would be useful for comparison. Since IEB has shown promise as a final waste form for the kind of waste being considered here, the waste stream compositions will be discussed in terms of IEB material composition ranges. The tolerance ranges for the major oxides, including TRU's, in IEB have been identilied previously, ${ }^{7, b}$ allhough in actuality, these ranges may be somewhat nebulous. Since the ratio of iron oxides to silica is a major indicator of IEB composition, it is this crileria that will be used exclusively in comparing the composition limits for the waste streams disscussed here. The listed silica content for IEB is 35 $57 \mathrm{wl} \%$, and iron oxide content is $10-35 \mathrm{wt} \%$. This presents a rather wide range of ratios from approximately 0.2 to 1.0. For A-40, the ratio is 0.384 .

The final composition for each type of waste, plus the amount of soil added, will be examined to see if it falls within the limits of an IEB composition. For instance, examination of Fig. 1 for the "average" waste shows that both the silica and iron oxide contents remain within the IEB wt\% ranges for below about $70 \mathrm{wt} \%$ soil. Above $70 \mathrm{wt} \%$ soil the silica content gocs above $57 \mathrm{wt} \%$ and the iron content below $10 \mathrm{wt} \%$.

Each waste stream can be analysed in the same manner, i.e. simply finding the range in each graph for which the silica and iron remain within the stated limits. In the case of the hydrated metal oxides, the amount of soil necessary for the slag to be within the iron oxide to silica range for IEB is $25-80 \mathrm{wt} \%$ soil for $\mathrm{H} 1$-series and $10-80 \mathrm{wt} \%$ soil for $\mathrm{H} 2$-series waste. The calcium silicated organics (S-series) fall within the correct range for $20-80 \mathrm{wt} \%$ soil additions, and Portland cemented organics (P-series) 30-65 wt\% soil additions. The evaporator salts or nitrates (N-series) require a $50-80 \mathrm{wt} \%$ soil addition, and the metal waste stream (M-series) needs a $55-85$ wt $\%$ addition of soil.

Although each waste stream has its own peculiarities reguarding the soil amounts needed to create an IEB waste form, it is important to point out that except for the metals waste stream, the stecl drum is vital in providing the iron content necessary for an IEB waste form. The evaporator salts, because of the extreme variation in composition, are a special case. The large percentage of soil becomes necessary to provide silica to the slag. Also, a potential problem exists due to high alkaline content of the slag. For instance, while a $50 \%$ soil addition results in a suitable iron-to-silica ratio $(0.61)$, the alkaline content $(\approx 40 \%)$ is higher than the preferred range and would decrease leach resistance. Leachability has been estimated as a function of alkaline content and slag composition, ${ }^{c}$ but the extent to which the alkali metals affect leachability needs to be validated experimentally. A processing solution to the problem would be to spread these salts throughout the waste stream or to add more soil to maintain FWF quality. In any case, the amount of this waste is very small and should not present any serious problem in terms of waste processing.

The metallic waste requires a large percentage of soil to be added not only to raise the silica content but to simultaneously reduce the amount of iron oxides. Since metals make up a

b. P. C. Kong, "Criteria and Requirements for Final Waste Form," Letter Report - Task 3.0 Criteria and Requirements for Final Waste Form - PCK-10-91, EG\&G Idaho, Inc., Interoffice Correspondence, Sept. 12, 1991.

c. J. D. Grandy, T. L. Eddy, and G. L. Anderson, Property and Process Correlations for Iron-Enriched Basalt, EGG-MS-11657, February 1993. 
substantial part of the stored waste, the entire processing schedule would have to include at least a $55 \mathrm{wt} \%$ soil addition unless a presorting method can be worked to spread out the high metal content waste in the processing stream. As an insurance factor, a $60 \mathrm{wt} \%$ soil addition would be recommended when processing a high metals content waste stream. Alternatives to a $60 \mathrm{wt} \%$ soil addition include (1) oxidizing only part of the metal, e.g., the contaminated surface, and tapping the remaining uncontaminated metal for recycle or low-level waste disposal or (2) sorting out the metal to a separate metal decontamination and recycling facility.

An important issue is the amount of contaminated soil that needs to be processed. Adding uncontaminated soil to the waste stream will increase the total waste volume, which is an undesirable option. If the amounts of contaminated soil are small compared to the total amount of waste, presorting the waste may become necessary. Ambitious presorting to spread the metals evenly throughout the waste stream input could reduce the soil input necessary to well below $40 \%$, but this possibility would need to be explored in more detail. 


\section{CONCLUSIONS AND RECOMMENDATIONS}

The composition limits of the waste stored at the RWMC have been analyzed to determine extremes of the input to a waste processing system. The resulting waste streams have been classified in a manner similar to the previous A-, B-, and C-series slags. They are the hydrous metal oxide sludges (H1- and H2-series), calcium silicate sludges for organies (S-series), Portland cemented organics (P-series), alkali nitrate sludges ( $\mathrm{N}$-series), and metals ( $\mathrm{M}$-series).

If enough soil $(>60 \mathrm{wt} \%$ ) is added to this waste stream, there should be no requirement for presorting of waste materials. There may be a considerable amount of contaminated soil requiring remediation. If more than $70 \mathrm{wt} \%$ soil is added to the input waste stream, based on the "average" waste stream composition (A-series), the resulting slag will not be an IEB waste form. This should not a problem however, since it will have a high silica content and will therefore fall into the catcgory of a glass-ceramic slag which would have suitable waste form characteristics also.

If less than $60 \mathrm{wt} \%$ soil is used for whatever reason, some modest presorting may be required to ensure that the resulting waste form falls into the IEB category. Since waste materials stored at the TSA are relatively well characterized for content and stored for easy retrieval, presorting and mixing prior to processing would be easier than with buried waste in the SDA.

Much less soil would be required if the metal in the input waste stream can be presorted and recovered or tapped during melting and recovered that way. This would increase the complexity of any waste processing scheme, but processing costs could be partially offset by the metals recovery operations.

In general, some contaminated soil or other additives will be necessary to process the waste in the TSA. It is recommended that to obtain an IEB glass-ceramic waste form without presorting or removing metal from the input waste streams, large soil additions of approximately $60 \mathrm{wt} \%$ be used. This will help create a robust processing system capable of handling all inputs regardless of the waste stream composition. 


\section{REFERENCES}

1. J. E. Flinn et al., Annual Report on the TRU Waste Form Studies with Special Reference to Iron-Enriched Basalt: 1980, EGG-FM-5366, June 1981.

2. D. A. Arrenholz and J. L. Knight, A Brief Analysis and Description of Transuranic Waste Disposal in the Subsurface Area of the Radioactive Waste Management Complex at the INEL, WTD-90-016, 1990.

3. M. J. Vigil, Subsurface Disposal Area Waste Identification (1952-1970 Emphasis), EGG-WM-8727, 1990.

4. T. L. Clements, Jr., Content Code Assessments for INEL Contact-Handled Stored Transuranic Wastes, WM-F1-82-(21, October 1982.

5. W. H. Landman, Jr., Rocky Flats Plant Sludge Compositions, Engineering Design File, SN TWTF-56, May 26, 1981.

6. W. Gardner, E. I. Cooke, and R. W. I. Cooke, Handbook of Chemical Synonyms and Trade Names, 8th edition, CRC Press, 1978.

7. D. E. Owen and J. E. Flinn, Iron-Enriched Basalt and Its Application to Three-Mile Island Radioactive Waste Disposal: A Brief Review, RE-M-81-004, EG\&G Idaho, Inc., April 1981 (Internal Report). 


\section{Appendix A}

Final Slag Compositions 


\section{Hydrated Metal Oxides}

Content Code: 1

RF Prefix: 741

Label: First Stage Sludge

Description/Content:

Waste sludge is produced by treating aqueous process wastes, generated by plutonium recovery operations. The treatment process produces a precipitate of the hydrated oxides of iron, magnesium, aluminum, silicon, etc. The precipitate is filtered to produce a sludge containing 50-70 wt\% water. The sluc' ze was double bagged in plastic bags inside 55-gal drums. Portland cement was added (40-50 lb) to the outer bag to absorb any free liquids. The drums were later topped with Oil-Dry (1-2 qt).

Assumptions:

In the final compositional ma'zeup, any organics (piastic bags, etc.) have been converted to $\mathrm{N}_{2}, \mathrm{CO}_{2}, \mathrm{H}_{2} \mathrm{O}$, etc.

Sludge composition is average first stage sludge as listed in Engineering Design File TWTF-55.

The steel drum is included as part of the waste form.

The table below gives slag composition for the RFP 741 hydrated metal oxide (H1-Series) waste as a function of mass of suil in the mixture.

\begin{tabular}{|l|l|l|l|l|l|l|l|l|l||}
\hline & $\mathrm{SiO}_{2}$ & $\mathrm{Al}_{2} \mathrm{O}_{3}$ & $\begin{array}{c}\mathrm{FeO}+ \\
\mathrm{Fe}_{2} \mathrm{O}_{3}\end{array}$ & $\mathrm{CaO}$ & $\mathrm{MgO}$ & $\mathrm{Na}_{2} \mathrm{O}$ & $\mathrm{K}_{2} \mathrm{O}$ & $\mathrm{TiO}_{2}$ & $\mathrm{Misc}$. \\
\hline $\mathrm{H} 1-0$ & 25.2 & 7.0 & 29.6 & 12.9 & 3.0 & 15.9 & 2.6 & 0.0 & 3.8 \\
\hline $\mathrm{H} 1-20$ & 33.2 & 8.2 & 24.6 & 12.4 & 2.9 & 13.1 & 2.6 & 0.1 & 3.0 \\
\hline $\mathrm{H} 1-40$ & 41.2 & 9.4 & 19.6 & 11.8 & 2.8 & 10.3 & 2.7 & 0.2 & 2.2 \\
\hline $\mathrm{H} 1-60$ & 49.3 & 10.6 & 14.5 & 11.3 & 2.6 & 7.4 & 2.7 & 0.4 & 1.5 \\
\hline $\mathrm{H} 1-80$ & 57.3 & 11.8 & 9.5 & 10.7 & 2.5 & 4.6 & 2.8 & 0.5 & 0.7 \\
\hline $\mathrm{H} 1-100$ & 65.4 & 13.0 & 4.5 & 10.2 & 2.4 & 1.7 & 2.9 & 0.6 & 0.0 \\
\hline
\end{tabular}




\section{Hydrated Mctal Oxides}

Content Code: 2

RF Pretix: 742

Label: Second Stage Sludge

Description/Content:

Waste sludge is produced by treating aqueous process wastes, generated by plutonium recovery operations. The treatment process produces a precipitate of the hydrated oxides of iron, magnesium, aluminum, silicon, etc. The precipitate is filtered to produce a sludge containing $50-70 \mathrm{wt} \%$ water. The sludge was double bagged in plastic bags inside 55 -gal drums. Portland eement was added (40-50 lb) to the outer bag to absorb any free liquids. The drums were later topped with Oil-Dry (1-2 qt).

Assumptions:

In the final compositional makeup, any organics (plastic bags, etc.) have been converted to $\mathrm{N}_{2}, \mathrm{CO}_{2}, \mathrm{H}_{2} \mathrm{O}$, ctc.

Sludge composition is average second stage sludge as listed in Enginecring Design File TWTF-55.

The steel drum is included as part of the waste form.

The table below gives slag composition for the RFP 742 hydrated metal oxide (H2-Serics) waste as a function of mass of soil in the mixture.

\begin{tabular}{|l|l|l|l|l|l|l|l|l|l||}
\hline & $\mathrm{SiO}_{2}$ & $\mathrm{Al}_{2} \mathrm{O}_{3}$ & $\begin{array}{c}\mathrm{FcO}+ \\
\mathrm{Fe}_{2} \mathrm{O}_{3}\end{array}$ & $\mathrm{CaO}$ & $\mathrm{MgO}$ & $\mathrm{Na}_{2} \mathrm{O}$ & $\mathrm{K}_{2} \mathrm{O}$ & $\mathrm{TiO}_{2}$ & Misc. \\
\hline $\mathrm{H} 2-0$ & 32.0 & 4.7 & 27.9 & 22.9 & 6.3 & 3.3 & 2.2 & 0.2 & 0.4 \\
\hline $\mathrm{H} 2-20$ & 38.7 & 6.4 & 23.2 & 20.4 & 5.5 & 2.9 & 2.3 & 0.3 & 0.3 \\
\hline $\mathrm{H} 2-40$ & 45.4 & 8.0 & 18.5 & 17.8 & 4.7 & 2.6 & 2.5 & 0.4 & 0.2 \\
\hline $\mathrm{H} 2-60$ & 52.0 & 9.7 & 13.9 & 15.3 & 4.0 & 2.3 & 2.6 & 0.4 & 0.2 \\
\hline $\mathrm{H} 2-80$ & 58.7 & 11.3 & 9.2 & 12.7 & 3.2 & 2.0 & 2.8 & 0.5 & 0.1 \\
\hline $\mathrm{H} 2-100$ & 65.4 & 13.0 & 4.5 & 10.2 & 2.4 & 1.7 & 2.9 & 0.6 & 0.0 \\
\hline
\end{tabular}




\section{Silicates (Calcium)}

Content Code: 3

RF Prefix: 743

Label: Organic Setups

Description/Content:

Organic wastes such as degreasing agents (trichloroethane), lathe coolants (Texaco Regal oil and carbon tetrachloride), and hydraulic and gearbox oils were mixed with calcium silicate to form a grease or paste-like material. The liquid organics were processed by mixing approximately 30 gal of organic wastes with $100 \mathrm{lb}$ of calcium sillicate (Johns-Manville product, Microcel E) and smaller amounts $(10-20 \mathrm{lb})$ of Oil-Dry. The material was bagged in plastic separately before being put into the 55-gal drums with additional Oil-Dry added to the top and bottom of the drum.

Assumptions:

For the final compositional makeup, all of the organics have been converted to $\mathrm{N}_{2}, \mathrm{CO}_{2}$, $\mathrm{H}_{2} \mathrm{O}$, etc.

The steel drum is included as part of the waste form.

A total of $20 \mathrm{lb}$ of Oil-Dry was used in processing.

The table below gives slag composition for the RFP 743 calcium silicated (S-Series) waste as a function of mass of soil in the mixture.

\begin{tabular}{|l|l|l|l|l|l|l|l|l|l||}
\hline & $\mathrm{SiO}_{2}$ & $\mathrm{Al}_{2} \mathrm{O}_{3}$ & $\begin{array}{l}\mathrm{FeO}+ \\
\mathrm{Fe}_{2} \mathrm{O}_{3}\end{array}$ & $\mathrm{CaO}$ & $\mathrm{MgO}$ & $\mathrm{Na}_{2} \mathrm{O}$ & $\mathrm{K}_{2} \mathrm{O}$ & $\mathrm{TiO}_{2}$ & Misc. \\
\hline $\mathrm{S}-0$ & 35.4 & 4.8 & 40.9 & 14.7 & 3.5 & 0.3 & 0.4 & 0.0 & 0.0 \\
\hline $\mathrm{S}-20$ & 41.4 & 6.4 & 33.6 & 13.8 & 3.3 & 0.6 & 0.9 & 0.1 & 0.0 \\
\hline $\mathrm{S}-40$ & 47.4 & 8.1 & 26.3 & 12.9 & 3.1 & 0.9 & 1.4 & 0.2 & 0.0 \\
\hline $\mathrm{S}-60$ & 53.4 & 9.7 & 19.1 & 12.0 & 2.8 & 1.1 & 1.9 & 0.4 & 0.0 \\
\hline $\mathrm{S}-80$ & 59.4 & 11.4 & 11.8 & 11.1 & 2.6 & 1.4 & 2.4 & 0.5 & 0.0 \\
\hline $\mathrm{S}-100$ & 65.4 & 13.0 & 4.5 & 10.2 & 2.4 & 1.7 & 2.9 & 0.6 & 0.0 \\
\hline
\end{tabular}




\section{Portland-Cemented Organics}

Content Code: 4

RF Prclix: 744

Labcl: Special Sctups

Description/Content:

Approximately 100$) \mathrm{L}$ of liquids composed of complexing chemical wastes such as alcohols, organic acids, etc., are mixed with $190 \mathrm{lb}$ of Portland eement and $50 \mathrm{lb}$ of pipe (magnesia) ecment. The mixture is placed in 55-gal stecl drums with an additional $10-1.5 \mathrm{lb}$ of eement to absorb excess moisture.

Assumptions:

For the final compositional makcup, all organics have been converted to $\mathrm{N}_{2}, \mathrm{CO}_{2}, \mathrm{H}_{2} \mathrm{O}$, etc.

The steel drum is included as part of the waste form.

The table below gives slag composition for the RFP 744 Portland-cemented (P-Series) waste as a function of mass of soil in the mixture.

\begin{tabular}{|l|l|l|l|l|l|l|l|l|l||}
\hline & $\mathrm{SiO}_{2}$ & $\mathrm{Al}_{2} \mathrm{O}_{3}$ & $\begin{array}{c}\mathrm{FcO}+ \\
\mathrm{Fc}_{2} \mathrm{O}_{3}\end{array}$ & $\mathrm{CaO}$ & $\mathrm{MgO}$ & $\mathrm{Na}_{2} \mathrm{O}$ & $\mathrm{K}_{2} \mathrm{O}$ & $\mathrm{TiO}_{2}$ & Misc. \\
\hline $\mathrm{P}-(0$ & 20.6 & 9.3 & 22.8 & 39.8 & 7.6 & 0.0 & 0.0 & 0.0 & 0.0 \\
\hline $\mathrm{P}-20$ & 29.6 & 10.0 & 19.1 & 33.9 & 6.6 & 0.3 & 0.6 & 0.1 & 0.0 \\
\hline P-40 & 38.5 & 10.8 & 15.5 & 29.0 & 5.5 & 0.7 & 1.2 & 0.2 & 0.0 \\
\hline P-60) & 47.5 & 11.5 & 11.8 & 22.0 & 4.5 & 1.0 & 1.7 & 0.4 & 0.0 \\
\hline P-80 & 56.4 & 12.3 & 8.2 & 16.1 & 3.4 & 1.4 & 2.3 & 0.5 & 0.0 \\
\hline P-100 & 65.4 & 13.0 & 4.5 & 10.2 & 2.4 & 1.7 & 2.9 & 0.6 & 0.0 \\
\hline
\end{tabular}




\section{Nitrates}

Content Code: 5

RF Prefix: 745

Label: Evaporator Salts

Description/Content:

Waste consists of a salt residue generated from concentrating and drying liquid waste from the solar evaporation ponds. The approximate chemical makeup of the salt is $60 \%$ sodium nitrate, $30 \%$ potassium nitrate and $10 \%$ miscellaneous. Limited amounts of other waste such as surgeons' gloves, paper, rags, and metal are included. The salts are contained in plastic bags in 55 -gal drums with small amounts (1-2 qt) of Oil-Dry.

Assumptions:

Eight percent of the waste is in the form of organics that have been converted to $\mathrm{N}_{2}, \mathrm{CO}_{2}$, $\mathrm{H}_{2} \mathrm{O}$, etc.

Two percent of the salt waste is in the form of iron oxides.

The steel drum is included as part of the waste form.

A total of $1.0 \mathrm{~kg}$ of Oil-Dry was used in processing.

The table below gives slag composition for the RFP 745 alkali nitrate evaporator salt ( $\mathrm{N}$-Series) waste as a function of mass of soil in the mixture.

\begin{tabular}{|c|c|c|c|c|c|c|c|c|c|}
\hline & $\mathrm{SiO}_{2}$ & $\mathrm{Al}_{2} \mathrm{O}_{3}$ & $\begin{array}{l}\mathrm{FeO}+ \\
\mathrm{Fe}_{2} \mathrm{O}_{3}\end{array}$ & $\mathrm{CaO}$ & $\mathrm{MgO}$ & $\mathrm{Na}_{2} \mathrm{O}$ & $\mathrm{K}_{2} \mathrm{O}$ & $\mathrm{TiO}_{2}$ & Misc. \\
\hline $\mathrm{N}-0$ & 0.7 & 0.3 & 36.1 & 0.1 & 0.0 & 37.3 & 25.5 & 0.0 & 0.0 \\
\hline $\mathrm{N}-20$ & 13.6 & 2.8 & 29.8 & 2.1 & 0.5 & 30.2 & 21.0 & 0.1 & 0.0 \\
\hline $\mathrm{N}-40$ & 26.6 & 5.4 & 23.5 & 4.1 & 1.0 & 23.1 & 16.5 & 0.2 & 0.0 \\
\hline $\mathrm{N}-60$ & 39.5 & 7.9 & $\mid 17.1$ & 6.2 & 1.5 & 15.9 & 11.9 & 0.4 & 0.0 \\
\hline $\mathrm{N}-80$ & 52.5 & 10.5 & 10.8 & 8.2 & 1.9 & 8.8 & 7.4 & 0.5 & 0.0 \\
\hline $\mathrm{N}-100$ & 65.4 & 13.0 & 4.5 & 10.2 & 2.4 & 1.7 & 2.9 & 0.6 & 0.0 \\
\hline
\end{tabular}




\section{Metals}

Content Code: 480

RF Prefix: N/A

Label: Unleached Light Nonspecial Source Metals

Description/Content:

The waste is a conglomeration of various metals in the form of gloveboxes, furnaces, lathes, drill presses, ducts, pipes, angle iron, tanks, control panels, electronics, pumps, motors, etc. Sharp edges were taped, and much material was bagged in plastic separately before being put into the 55-gal drums or boxes.

Assumptions:

For the final compositional makeup, any organics have been converted to $\mathrm{N}_{2}, \mathrm{CO}_{2}, \mathrm{H}_{2} \mathrm{O}$, etc.

A steel drum is included as part of the waste form.

Geneıd waste composition:

Glass $\left(\mathrm{SiO}_{2}\right)$

$-0.3 \%$

Steel $(\mathrm{Fe}(99 \%)+\mathrm{C}(1 \%))$

$-53.0 \%$

Stainless steel $(\mathrm{Fe}(74 \%), \mathrm{Cr}(18 \%), \mathrm{Ni}(8 \%))$

$-10.3 \%$

Other metal $(\mathrm{Cu}, \mathrm{Al}, \mathrm{Pb}, \mathrm{Ta}, \mathrm{Ni}, \mathrm{Zn}, \mathrm{Cd}, .$.

$-25.0 \%$

Combustibles

$-5.0 \%$

Concrete,dirt,ash,oil-dri,vermiculite $\left(\mathrm{SiO}_{2}(50 \%)+\mathrm{CaO}(25 \%)+\mathrm{Al}_{2} \mathrm{O}_{3}(20 \%)+\mathrm{FeO}(5 \%)\right) \quad-6.5 \%$ 
The table below gives slag composition for the nonspecial source metallic (M-Series) waste as a function of mass of soil in the mixture.

\begin{tabular}{|l|l|l|l|l|l|l|l|l|l||}
\hline & $\mathrm{SiO}_{2}$ & $\mathrm{Al}_{2} \mathrm{O}_{3}$ & $\begin{array}{c}\mathrm{FeO}+ \\
\mathrm{Fe}_{2} \mathrm{O}_{3}\end{array}$ & $\mathrm{CaO}$ & $\mathrm{MgO}$ & $\mathrm{Na}_{2} \mathrm{O}$ & $\mathrm{K}_{2} \mathrm{O}$ & $\mathrm{TiO}_{2}$ & $\mathrm{Misc}$. \\
\hline $\mathrm{M}-0$ & 2.5 & 5.1 & 75.1 & 1.0 & 0.0 & 0.0 & 0.0 & 0.0 & 16.3 \\
\hline $\mathrm{M}-20$ & 15.1 & 6.7 & 61.0 & 2.8 & 0.5 & 0.3 & 0.6 & 0.1 & 13.0 \\
\hline $\mathrm{M}-40$ & 27.7 & 8.3 & 46.9 & 4.7 & 1.0 & 0.7 & 1.2 & 0.2 & 9.8 \\
\hline $\mathrm{M}-60$ & 40.2 & 9.8 & 32.0 & 6.5 & 1.5 & 1.0 & 1.7 & 0.4 & 6.5 \\
\hline $\mathrm{M}-80$ & 52.8 & 11.4 & 18.6 & 8.4 & 2.0 & 1.4 & 2.3 & 0.5 & 3.3 \\
\hline $\mathrm{M}-100$ & 65.4 & 13.0 & 4.5 & 10.2 & 2.4 & 1.7 & 2.9 & 0.6 & 0.0 \\
\hline
\end{tabular}



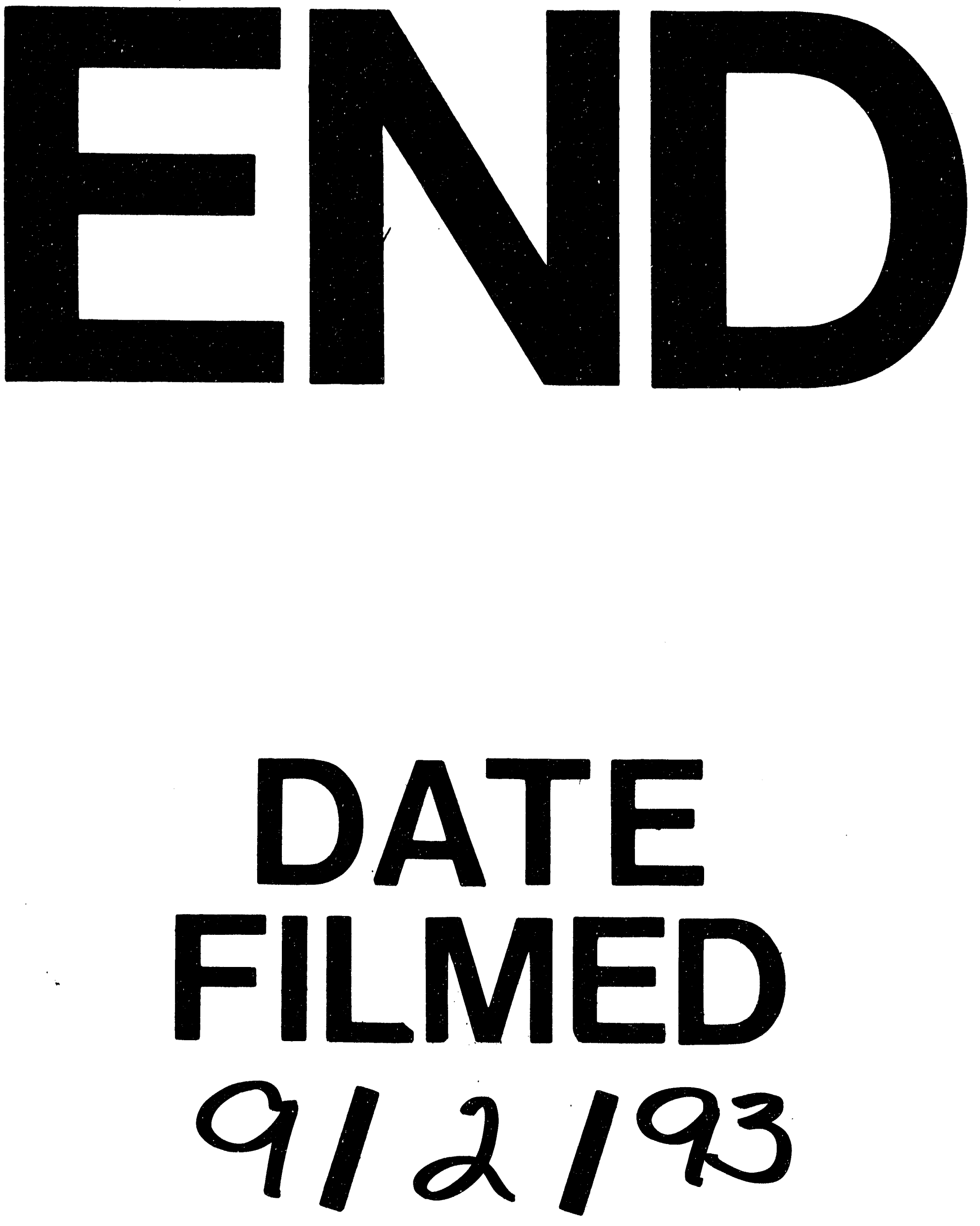
. 